BASINDO : Jurnal Kajian Bahasa, Sastra Indonesia, dan Pembelajarannya

Volume 2 Nomor 1, 2018

Journal homepage : http://journal2.um.ac.id/index.php/basindo

\title{
TRILOGI NOVEL SANG PEMBAHARU: PERJUANGAN DAN AJARAN SYAIKH SITI JENAR (KAJIAN POSTMODERN JEAN FRANCOUIS LYOTARD)
}

\author{
Arisni Kholifatu* \\ Pendidikan Bahasa dan Sastra Indonesia, Universitas Negeri Surabaya, Indonesia
}

\begin{tabular}{|c|c|}
\hline A R T ICLE I NFO & A B S T R ACT \\
\hline $\begin{array}{l}\text { Keyword: } \\
\text { Pembaharu, } \\
\text { postmodern, } \\
\text { delegitimasi, } \\
\text { permainan bahasa, } \\
\text { fragmentasi, } \\
\text { paralogi, } \\
\text { instabilitas }\end{array}$ & $\begin{array}{l}\text { Tujuan penelitian ini untuk menemukan dan mendeskripsikan (1) delegitimasi (2) } \\
\text { permainan Bahasa ( } 3 \text { ) fragmentasi (4) paralogi (5) instabilitas dalam novel Sang } \\
\text { Pembaharu Perjuangan dan Ajaran Syaikh Siti Jenar karya Agus Sunyoto. Metode penelitian } \\
\text { kualitatif dengan teknik analisis deskriptif berdasarkan pengungkapan atau penafsiran } \\
\text { atas rujukan atau sumber data. Hasilnya ditemukan tiga hal yaitu: pertama, delegitimasi } \\
\text { penolakan keputusan pemimpin atau penguasa. kedua, Permaianan bahasa merupakan } \\
\text { sebuah ikatan sosial yang mempersatukan masyarakat dalam berkomunikasi. Ketiga, } \\
\text { fragmentasi merujuk pada ketiadaan atau tidak berkembangnya koneksi di antara } \\
\text { masyarakat dan pengelompokan masyarakat berdasarkan semua aspek. keempat, Paralogi } \\
\text { kesepakatan guna perbaikan sebuah tatanan aturan yang berlaku. Kelima, Instabilitas } \\
\text { berupa ketidakmapanan akan sesuatu kondisi tertentu. }\end{array}$ \\
\hline
\end{tabular}

\section{PENDAHULUAN}

Pengetahuan naratif dan pengetahuan ilmiah yang ada dalam novel dapat berhubungan dengan masalah sosial, politik, budaya, dan agama, baik yang dialami oleh masyarakat pedesaan, masyarakat perkotaan, masyarakat kelas bawah, masyarakat kelas menengah, dan masyarakat kelas elit. Sebagai contoh, masalah masyarakat bisa masalah yang dihadapi masyarakat kecil dan miskin yang pada umumnya tinggal di daerah pedesaan, yang rumahnya terbuat dari sesek bambu, beratap alang-alang, dan berlantai tanah. Mereka tidak mempunyai kebebasan dan kekuasaan apa-apa. Mereka selalu terikat hidupnya dengan orang lain, terutama dari para majikan atau "doro". Mereka tidak mempunyai kebebasan dan kekuasaan karena hidupnya terikat pada orang lain. Mereka bisa makan juga karena jasa, pertolongan, dan belas kasihan dari orang lain, kelas elit atau "doro". Masalah agama bisa terkait dengan masalah keimanan, ibadah, tarekat, syareat, hakikat, dan makrifat.

Masalah masyarakat elit bisa menggambarkan kekuasan, kekayaaan, dan pengaruhnya di dalam masyarakat. Masyarakat tradisional bisa menggabarkan ketidakberdayaan, kemiskinan, keterikatan dengan orang lain atau masyarakat elit, dan penderitaan, dan kebodohannya(Ramadhanti, 2018). Masyarakat maju bisa menggambarkan kemajuan dalam penguasan pengetahuan, teknologi, kekuasaan, dan kewenangan, dan legitimasi dalam pengambilan keputusan.

Novel Agus Sunyoto merupakan karya sastra yang menarik karena berisi pemikiran, pengetahuan, sejarah, dan tanggapan pengarang terhadap ajaran dan pemikiran Syaikh Siti Jenar tentang kemanusiaan dan agama yang merujuk pada kitab-kitab versi Cirebon dengan cara pandang yang berbeda dengan pandangan masyarakat pada umumnya. Agus Sunyoto merupakan salah satu sastrawan yang mampu menghasilkan tujuh novel yang berisi ajaran dan pemikiran Syaikh Siti Jenar. Novel tersebut ditulis berdasarkan penelitian kualitatif yangbersumber naskah-nakah Cirebon dan Banten, sehingga menghasilkan pemikiran pengarang yang berbeda dengan anggapan masyarakat pada umumnya tentang Syaikh Siti Jenar yang dianggap menyimpang dari ajaran Islam sehingga dihukum mati oleh Wali Sanga.

\footnotetext{
" Corresponding author.

E-mail addresses: Arisnikholifatu@yahoo.co.id (Arisni Kholifatu)
}

ISSN : 2579-3799 (Online) - BASINDO : Jurnal Kajian Bahasa, Sastra Indonesia, dan Pembelajarannya is licensed under Creative Commons Attribution-ShareAlike 4.0 International License (http://creativecommons.org/licenses/BY/4.0/).

14 | BASINDO : Jurnal Kajian Bahasa, Sastra Indonesia, dan Pembelajarannya 
Pemikiran pengarang tentang perjalanan rohani Syaikh Siti Jenar tersebut dibumbui dengan imajinatif dan kreatifitas pengarangnya.

Melalui hasil penelitian secara kualitatif dan pendekatan secara verstehen yang bersumber dari naskah -naskah Cirebon dan Banten, Agus Sunyoto mampu menggambarkan figur tokoh Syaikh Siti Jenar secara utuh beserta ajarannya dalam ketujuh novelnya. Yangmenarik adalah Agus Sunyoto mampu menggambarkan tokoh Syaikh Siti Jenar berdasarkan pemahamannya yang berbeda dengan pandangan dan pencitraan masyarakat pada umumnya yang memandang tokoh Syaikh Siti Jenar adalah tokoh yang negatif, yang mengajarkan ajaran yang sesat dan tidak sesuai dengan ajaran Islam, sehingga dihukum mati oleh Wali Sanga di Demak (Sunyoto, 2006: xix-xx).

Meskipun hasil penelitian Agus Sunyoto tersebut menggunakan pendekatan penelitian kualitatif dan pendekatan vertehen, namun tidak dinamakan sejarah atau buku ilmiah, tetapi dinyatakan dalam bentuk fiksi atau novel, sehingga tidak menimbulkan perbedaan tentang kebenaran yang ada dalam novel tersebut, karena novel merupakan karya imajinatif dan fiktif, meskipun novel merupakan hasil refleksi dan endapan perenungan kontemplasi, pengalaman rohani pribadi, dan imajinasi pengarangnya (Sunyoto, 2006:xxii).

Novel pertama dan kedua berjudul Suluk Abdul Jalil Perjalanan Rohani Syaikh Siti Jenar. Novel pertama, berisi tentang Yang Wujud dan maujud serta pengalaman rohani Syaikh Siti Jenar sampai berangkat menjalankan ibadah haji ke Mekah. Di Mekah Syaikh Siti Jenar bertemu dengan Abu Bakar AshShidiq yang mengajarkan tarekat kepadanya (Sunyoto, 2006: vi). Novel kedua, merupakan kelanjutan dari novel pertama yang berisi tentang, sejarah Syaikh Siti Jenar setelah kembali dari Mekah ke tanah Jawa dan menyebarkan ajarannya sampai diangkat menjadi Dewan Wali Sanga (Sunyoto, 2006: vi).

Novel ketiga, keempat, dan kelima terkenal dengan Trilogi Novel Syaikh Siti Jenar. Ketiga novel tersebut berjudul Sang Pembaharu: Perjuangan dan Ajaran Syaikh Siti Jenar (SPPASJ). Ketiga novel tersebut berisi perjuangan dan ajaran Syaikh Siti Jenar dalam mewujudkan masyarakat baru, yaitu masyarakat yang memiliki kebebasan berpendapat,memiliki kesamaan hak dan derajat, dan memiliki hak milik tanah dan papan untuk melindungi dan membahagiakan keluarganya. Di samping itu, juga banyak berisi pengetahuan naratif dan ilmiah tentang berbagai masalah kemanusiaan yang terkait dengan pergulatan sosio-religi, idiologi, dokma, doktrin, dan pengalaman rohani Syaikh Siti Jenar (Sunyoto, 2004:vii).

Novel keenam dan ketujuh berjudul Suluk Malang Sungsang: Konflik dan Penyimpangan Ajaran Syaikh Siti jenar. Kedua novel tersebut memuat kisah akhir hidup Syaikh Siti Jenar yang mengandung banyak teka-teki dan menimbulkan banyak pertanyaan apakah Syaikh Siti Jenar mati atau tidak mati, atau dimatikan? Di samping itu, juga berisi bagaimana orang-orang memahami ajarannya. Dalam kedua novel tersebut juga banyak mengajarkan tentang kematian, karena manusia akan mati, maka ia harus belajar kematian, mengakrapi kematian dan mencintai kematian. Ajaran tentang kematian tersebut ternyata juga menimbulkan berbagai kesan dan pandangan beragam bagi masyarakat yang belum memahami secara dekat baik pribadi maupun ajarannya. Ada yang menganggap Syaik Siti Jenar atau Syaikh Lemah Abang mengajarkan ajaran yang sesat tentang kematian: mati adalah hidup dan hidup adalah mati. Ada juga yang menganggap Syaikh Lemah Abang sesat karena telah mengajarkan pengikutnya untuk bunuh diri mencari mati. Bahkan ada yang berpendapat bahwa Syaikh Lemah Abang adalah kematian itu sendiri, Sang Pencabut Nyawa, maka barang siapa yang dekat dengannya akan mati. Kematian adalah merah dan merah adalah kematian. Lemah abang yang bermakna tanah merah adalah tanah kematian (Sunyoto, 2005: 9). Di novel keenam dan ketujuh juga berisi lanjutan tentang cita-cita Syaikh Siti Jenar atau Syaikh Lemah Abang mewujudkan masyarakat baru atau zaman baru, yaitu dengan mendobrak segala sekat-sekat yang menghambat terwujudnya kebenaran dan telah menegakkan rambu-rambu kepada pengikutnya agar tidak menjadi penghalang bagi terwujudnya kebenaran (Sunyoto, 2006:16).

Novel SPPASJ juga menggambarkan ciri masyarakat lama dan masyarakat baru. Masyarakat lama ditandai dengan adanya perbedaan kelas atas dan kelas bawah. Kelas atas bercirikan besarnya kekayaan, tingginya penghasilan, tingginya tingkat pendidikan, pengaruh baik dalam sektor-sektor masyarakat perseorangan ataupun umum, dan kestabilan kehidupan keluarga, sedangkan kelas bawah atau tradisional biasanya terdiri dari kaum buruh kasar, penghasilannya pun relatif rendah sehingga mereka tidak mampu menabung, lebih berusaha memenuhi kebutuhan sehari-hari terutama masalah makan, daripada memenuhi kebutuhan masa depan, berpendidikan rendah, dan penerima dana kesejahteraan dari pemerintah.

Masyarakat baru ditandai dengan penguasaan pengetahuan dan teknologi, berorientasi pada dirinya sendiri, tidak membedakan adanya kelas atas dan kelas bawah.Masyarakat dianggap saling menghormati, menghargai dan mengakui keberadaan mereka masing-masing sesuai dengan keinginannya, sesuai dengan ajaran Islam.Setiap manusia memiliki kodrati ingin bebas, dihargai, dihormati, memiliki 
kesamaan hak, dan memiliki hak milik tanah dan rumah sebagai tempat tinggal dan menghidupi keluarganya.

Berdasarkan latar belakang tersebut, maka fokus penelitian ini dapat dirumuskan sebagai berikut: Delegitimasi dalam Novel Sang Pembaharu: Perjuangan dan Ajaran Syaikh Siti Jenar Karya Agus Sunyoto, Permainan Bahasa dalam Novel Sang Pembaharu Perjuangan dan Ajaran Syaikh Siti Jenar Karya Agus Sunyoto, Fragmentasi dalam Novel Sang Pembaharu Perjuangan dan Ajaran Syaikh Siti Jenar Karya Agus Sunyoto, Paralogi dalam Novel Sang Pembaharu Perjuangan dan Ajaran Syaikh Siti Jenar Karya Agus Sunyoto, Instabilitas dalam Novel Sang Pembaharu Perjuangan dan Ajaran Syaikh Siti Jenar Karya Agus Sunyoto

Secara etimologis postmodern merupaakan gabungan dari dua kata post dan modern. Kata post dapat bermakna setelah. Kata modern dapat bermakna baru. Kedua kata tersebut bila disatukan menjadi postmodern. Kata postmodern digunakan oleh Jean-Francois Lyotard untuk menggambarkan kondisi perkembangan pengetahuan di masyarakat yang peradabannya maju dengan cepat, yang berbeda dengan keadaan pada zaman modern. Teori postmodern ini juga merupakan reaksi atau kritik terhadap keadaan zaman modern yang tidak lagi sesuai dengan perkembangan masyarakat. Kata postmodern saat ini sudah banyak dipakai oleh para ahli sosiolinguistik dan kritik di Amerika digunakan untuk memperlihatkan keadaan budaya masyarakat yang sudah mengalami proses transformasi yang sudah dimulai sejak akhir abat ke sebilan belas, telah mengubah aturan main dalam sains, sastra, dan seni (Lyotard, 1984: 1; Wolfreys: 378; Kivisto, 2008: 463).

Menurut Lyotard (1984: 2) postmodern merupakan sebuah bentuk keraguan terhadap metanarasi, terutama terhadap keusahaan perangkat metanarasi terhadap legtimasinya. Keraguan tersebut merupakan sebuah produk dari hasil perkembangan sains sehingga nantinya sains akan memisahkan dirinya dari pengetahauan narasi. Metanaratif semakin kehilangan fungsinya, kehilangan pahlawan besarnya, bahaya besarnya, perjalanan terbesarnya, dankehilangan tujuan besarnya. Fungsi narasi menjadi tersebar dalam awan-awan elemen narasi bahasa yang akan bersifat denotatif, preskriptif, dan deskriptif. Tersampaikan dalam setiap awan tersebut adalah tingkatan-tingkatan pragmatik yang sesuai dengan jenis dan tipenya. Setiap manusia hidup berada dalam persimpangan dari tingkatan pragmatik. Dengan demikian, masyarakat di masa depan akan berada dalam wilayah antropologi Newtonian seperti strukturalisme atau teori sistem dibandingkan dengan pragmatik partikel-partikel bahasa sehingga akan banyak sekali permainan bahasa dalam kehidupan masyarakat.

Para pengambil keputsan berusaha mengelola awan-awan tersebut berdasarkan matrik input dan outputnya mengikuti sebuah logika yang menjelaskan elemen-elemen yang sepadan dan secara keseluruan dapat ditentukan dan diatur. Demikian juga dalam menentukan keadilansosial dan kebenaran ilmiah. Legitimasi kekuasan tersebut akan berdasarkan pada dasar pemikiran pengoptimalan sistem yang disebut efisiensi.

\section{METODE PENELITIAN}

Penelitian ini merupakan penelitian kualitatif. Melalui rancangan yang digunakan tersebut, penelitian dapat ditentukan kebenaran atau kesalahan penjelasan mengenai fakta yang dijadikan objek sasaran. Menurut Marshall dan Rossman (2006:3); Emzir (2014;2-5); Thomas (2003:1-2) penelitian kualitatif adalah penelitan yang bersifat natural, data deskriptif, mementingkan proses, bersifat induktif, menggunakan multimetode, terfokus pada konteks, dan mementingkan interpretasi dalam rangka menemukan makna. Penelitian kualitatif bertujuan menggambarkan dan mendeskripsikan secara tepat sifat-sifat suatu individu, atau fenomena sosial. Metode kualitatif memberikan perhatian terhadap data alamiah, data dalam hubungannya dengan konteks keberadaanya. Cara-cara inilah yang mendorong metode kualitatif dianggap sebagai multimetode sebab penelitian pada gilirannya melibatkan sejumlah besar gejala sosial yang relevan. Dalam penelitian karya sastra, misalnya akan dilibatkan pengarang, lingkungan sosial di mana pengarang berada, termasuk unsur-unsur kebudayaan pada umumnya.

Sejalan dengan pendapat tersebut, dalam penelitian ini menggunakan metode penelitian kualitatif. Penggunaan metode kualitatif ini dengan beberapa alasan sebagai berikut:(1) data penelitian sastra tidak mengunakan angka-angka, sehingga tepat apabila menggunakan rancangan penelitian kualitatif, (2)data penelitian ini berupa data deskriptif sesuai fokus penelitian.penelitian, (3) peneliti bertindak sebagai instrumen penelitian, (4) penelitian ini lebih mengutakan proses dan produk, dan (5) penelitian ini lebih menekankan pada pendeskripsian makna data karena pada dasarnya penelitian kualitatif lebih menekankan pada makna data.

Sumber data penelitian ini adalah Trilogi novel Sang Pembaharu: Perjuangan dan Ajaran Syaikh Siti Jenar (SPPAJS) karya Agus Sunyoto, buku tiga, empat, dan lima. Novel ini diterbitkan oleh Pustaka Sastra LKIS Yogyakarta, tahun terbit 2006.Ketiga novel ini dipilih sebagai sumber data karena Trilogi Novel Sang 
Pembaharu: Perjuangan dan Ajaran Syaikh Siti Jenar karya Agus Sunyoto menarik karena banyak mengandung banyak pengetahuan naratif,pengetahuan ilmiah,permainan bahasa, kekuasaan, dan legtimasi,ikatan sosial yang membentuk masyarakat tradisional dan masyarakat maju, danpembaruan untuk mencapai masyarakat maju atau baru serta sesuai dengan teori Postmodern Lyotard.

Data penelitian ini mencakup: (1) Delegitimasi dalam Novel Sang Pembaharu: Perjuangan dan Ajaran Syaikh Siti Jenar Karya Agus Sunyoto, (2) Permainan Bahasa dalam Novel Sang Pembaharu Perjuangan dan Ajaran Syaikh Siti Jenar Karya Agus Sunyoto, (3) Fragmentasi dalam Novel Sang Pembaharu Perjuangan dan Ajaran Syaikh Siti Jenar Karya Agus Sunyoto, (4) Paralogi dalam Novel Sang Pembaharu Perjuangan dan Ajaran Syaikh Siti Jenar Karya Agus Sunyoto, dan (5) Instabilitas dalam Novel Sang Pembaharu Perjuangan dan Ajaran Syaikh Siti Jenar Karya Agus Sunyoto.

Teknik pengumpulan data dalam penelitian ini menggunakan metode dokumentasi atau pustaka. Metode dokumentasi atau pustaka adalah metode yang digunakan untuk menelusuri dan mengumpulkan data yang berupa dokumen novel novel Sang Pembaharu: Perjuangan dan Ajaran Syaikh Siti Jenar karya Agus Sunyoto, buku tiga, empat, dan lima.

Teknik analisis data penelitian ini menggunakan teknik analisia deskriptif. Analisis deskriptif merapakan prosedur analisis data dengan cara menggambarkan atau melukiskan keadaan suatu subjek atau objek penelitian yang berdasarkan fakta-fakta baik berupa fenomena, fakta, atau kejadian, sehingga pembaca dapat memahami secara mudah.

Teknik yang digunakan untuk menguji keabsahan data dalam penelitian ini menggunakan (1) membaca terus menerus secara teliti terhadap novelSang Pembaharu: Perjuanga dan Ajaran Syaikh Siti Jenarkarya Agus Sunyoto untuk menemukan makna data yang ada dalam novel tersebut, (2) diskusi dengan teman sejawat, sehingga pemahaman terhadap makna teks novelSang Pembaharu: Perjuanga dan Ajaran Syaikh Siti Jenarkarya Agus Sunyoto benar, (3) pemeriksaan para pakar, draft Tesis akan dikonsultasikan kepada pakar satra yang memahami tentang teori postmodern J.F. Lyotard, yaitu Prof. Dr. Suyatno dan Dr. Kamidjan.

\section{HASIL PENELITIAN}

\section{Delegitimasi dalam Novel Sang Pembaharu: Perjuangan dan Ajaran Syaikh Siti Jenar Karya Agus Sunyoto}

Pada umumnya adanya legitimasi yang dimiliki oleh seorang pemimpin atau penguasa bisa memicu kestabilan pada suatu situasi dan kondisi. Hal tersebut juga dipercaya dapat membuka kesempatan yang semakin lebar bagi pemerintah atau penguasa untuk tidak hanya memperluas bidang tertentu. Sedangkan delegitimasi merupakan ketidakabsahan mengenai suatu kaidah-kaidah konvensional sejak akhir abad ke 19 sebagai akibat perkembangan teknologi dan ekspansi kapitalisme. Dalam masyarakat pascaindustri, ilmu mengalami delegitimasi. Jadi, delegitimasi merupakan kondisi yang menunjukkan bahwa penolakan keputusan pemimpin atau penguasa pelaksana kekuasaan. Gambaran mengenai delegitimasi tampak pada data berikut:

"Ketahuilah, o puteraku, sesungguhnya aku tidak memberati jabatan apa pun di dunia ini. Namun, dengan cara bagaimana kau bisa mengakhiri jabatan chakrabhumi? Bukankah hal itu akan membangkitkan amarah seluruh penghuni Bumi Pasundan?" (D1/AS-SPPASSJ/3-110)

Data tersebut mengisyaratkan bahwa Abdul Jalil memiliki gagasan untuk merubah tatanan yang ada berdasarkan konsep yang sesuai dengan keyakinan yang dianutnya. Hal itu terkait dengan konsep delegitimasi Lyotard mengenai penolakan keputusan pemimpin atau penguasa pelaksana kekeuasaan. Konsep tersebut juga nampak pada data berikut.

Mendengar penjelasan Abdul Jalil, Syaikh Datuk Kahfi bisa memahami. Ahirnya, dia hanya bisa berdiam diri sambil mengawasi sekaligus berdoa agar apa yang dilakukannya oleh Abdul Jalil dapat diwujudkannya sesuai harapan. Demikianlah, bagaikan sedang menyaksikan seseorang seniman mengubah benda-benda bisa menjadi kaya bernilai seni tinggi, Syaikh Datuk Kahfi dengan takjub menyaksikan Abdul Jalil melakukan pengembangan seni mendidik di padepokan yang didirikannya tersebut dengan cara-cara yag sangat mencengangkan. (D2/AS-SPPASSJ/3-196)

Data tersebut tesebut menjelakan tentang kegamuman Syaikh Datuk Kahfi terhadap kreativitas lokal yang dilakukan Abdul Jalil dalam hal pendidikan. Uraian tersebut memiliki keterkaitan sesuai dengan konsep Lyotard tentang delegitimasi yakni dari konsep tatanan pendidikan lama ke konsep pendidikan yang baru.

Dalam novel juga terdapat delegitimsi yang dialami ang Hyang Semar akibat ilmu seratus ribu hulu balang di dalam diri Sri Mangana, yang membikin Dang Hayang semar tidak suka. Percakapan Abdul Jalil dan Sri Mangan nampak pada data berikut. 
“ Beliau menyatakan kepada ananda bahwa di dalam diri Ramanda Ratu bersemayam kekuatan kelam ilmu seratus ribu hulubalang dari Gunung Kumbha(ng). Ilmu itu pengaruh Bhairawa haus darah yang tidak beliau sukai.".. Astaghfirullah!" Sahut Sri Mangana dengan wajah pucat." Bagaimana beliau bisa tahu?" (D3/AS-SPPASSJ/4-130)

Data tersebut menjelaskan bahwa Dang Hyang Semar tidak suka kepada Sri Mangana, karena dia masih memiliki ilmu seratu ribu hulubalang yang bersemayam di dirinya. Sri Mangana pun percaya atas ucapan Abdul Jalil. Abdul Jalil dianggap berkuasa dan mampu memiliki ilmu yang lebih. Uraian tersebut sesaui dengan konsep Lyotard tentang delegitimsi, yaitu Dang Hyang Semar tidak menyukai Sri Mangana, meskipun Sri Mangana seorang raja, namun ilmu Bhirawa yang dimiliki Sri Mangan membuat Dang Hyang Semar tidakmenyukainya, karena ilmu tersebut haus darah, dan akan makan korban. Dang Hyang Semar menginginkan ilmu itu dihapus dari diri Sri Mangana.

\section{Permainan Bahasa dalam Novel Sang Pembaharu Perjuangan dan Ajaran Syaikh Siti Jenar Karya Agus Sunyoto}

Permaianan bahasa merupakan sebuah ikatan sosial yang mempersatukan masyarakat dalam berkomunikasi. Permainan bahasa mampu menunjukkan kewenangan seseorang yang telah diberi mandat kewenangan. Dalam konteks permainan bahasa sebagai alat komunikasi, bahwa setiap klausa atau kalimat yang diucapkan atau disampaikan kepada orang lain, mengandung tiga aspek, yaitu pengirim, penerima, dan refrennya. Pihak pengirim pesan jelas memunyai posisi yang berwenang, yang menginginkan agar penerima pesan untuk melakukan tindakan yang diinginkannya. Menurut Lyotarad, kekuasaan seseorang bisa dilihat dari penggunaan bahasa atau permainan bahasa. Pendapat penguasa dapat dieprcaya kepada pendengarnya, hal tersebut bentuk kekuasaan dan legitimasi terhadap pendapat atau perintah penutur. Pada trilogi novel SPPASSJ juga terdapat permainan bahasa berikut.

"Ramanda Ratu adalah Sang Chakrabhumi, penguasa Khabumian. Jika Ramanda Ratu mencintai jabatan maka Ramanda Ratu tidak memenuhi keinginan beliau. Ramanda Ratu setiap saat bisa meminta bantuan dari arwahnya untuk menyelesaikan." (D6/AS-SPPASSJ/3-109)

Data tersebut menjelaskan bahwa Abdul Jalil menyatakan pendapatnya tentang jabatan yang dimiliki Ramanda Ratu di tanah Caruban. Atas jabatannya tetrsebut Ramanda Ratu boleh memakai kekuasaannya boleh tidak. Hal ini sesuai dengan konsep Lyotard tentang permainan bahasa, Meskipun Ramanda Ratu memiliki legitimasi namun dia tetap menerima pendapat Abdul Jalil, dia tetap memikirkan segala seuatu yang diucapkan oleh Abdul Jalil.

"Namun, dengan kekuatan dan kuasa ruh yang paduka miliki, Paduka bisa

memerintahkan kami untuk mempermudah perjalanan Paduka mencapai puncak."(D7/ASSPPASSJ/4-20)

Data tersebut menjelaskan meskipun Abdul Jalil kekuasaan tentang ilmu, namun dia tidak menggunakan deligitimasinya untuk mencapai segala keinginannya. Dengan kekuatan yang dimilikinya ini membuktikan bahwa Abdul Jalil merupakan orang berkuasa. Dari data di asat sesuai konsep Lyotard tentang permainan bahasa, karena muridnya memanggil paduka dan Abdul Jalil memiliki kekuatan yang mampu mencapai keinginannya.

Lalu, diputuskanlah oleh ayahandaku untuk menyelesaikan perkara samiddha melalui jalan damai perundingan. Demikianlah setelah melalui beberapa kali pertemuan akhirnya kedua belah pihak yang berselisih mencapai kesepakatan, yaitu Ario Abdillah Yang Dipertuan Palembang sebagai penengah. (D8/AS-SPPASSJ/3-83)

Data tersebut menjelaskan bahwa telah terjadi kesepakatan antara Raden Pamanah Rasa dengan kedua belah pihak yang berselisih. Sebelumnya Raden Pamanah Rasa yang mengambil keputusan, karena dia yang yang berkuasa di daerah tersebut, tetapi dia juga mengajak rudingan pihak yang berselisih agar menemukan kesepakatan dan tidak menimbulkan perselisihan. Kesepakatan telah terjadi untuk menunjuk Yang Mulia Ario Abdillah sebagai penengah untuk masalah samiddha Caruban Larang.

\section{Fragmentasi dalam Novel Sang Pembaharu Perjuangan dan Ajaran Syaikh Siti Jenar Karya Agus} Sunyoto

Fragmentasi merujuk pada ketiadaan atau tidak berkembangnya koneksi di antara masyarakat dan pengelompokan masyarakat berdasarkan semua aspek. Fragmentasi berisi interupsi dan penjajaran yang mengacaukan kaidah-kaidah konvensionl. Hal ini sesuai dengan data berikut.

"Karena segala sesuatu telah berubah maka aku pun akan melakukan sedikit perubahan atas butirbutir perjanjian yang telah disepakati oleh Dang Hyang Semar dan leluhur kalian." (D14/ASSPPASSJ/4-28) 
Data tersebut menjelaskan bahwa Abdul Jalil ingin melakukan perubahan terhadap kebijakan yang dibuat Dang Hyang Semar sebelumnya. Hal itu sesuai dengan konsep Lyotard mengenai Fragmentasi bahwa fragmentasi ini merupakan interupsi berwujud perubahan yang ingin dilakukanAbdul Jalil terhadap janji yang telah disepakati oleh Dang Hyang Semar dan leluhurnya.

Dengan memahami dan menyadari bahwa tiap-tiap manusia adalah wakil al-haqq di muka bumi maka keberadaan tiap-tiap manusia wajib diakui, dihargai, dan dihormati sebagai pribadi yang memiliki hak fitrah sebagai makhluk paling sempurna. Dalam novel terdapat fragmentasi yang dilakukan Abdul Jalil, taitu tampak dalam data berikut.

"Tidak peduli seseorang berkdudukan sebagai raja, pangeran, nayakapraja, pedagang, petani, kuli, bahkan budak sekalipun, secara fitrah memiliki hak untuk bebas menyatakan kebenaran."(D15/ASSPPASSJ/4-94)

Data tersebut menjelskan bahwa setiap manusia memiliki hak yang sama untuk menyampaikan kebenaran. Seperti yang dilakukan Abdul Jalil untuk masyarakat Caruban, agar masyarakat tanpa takut menyatakan kebenaran demi mencapai masyarakat yang baru dan menjadi manusia mulia sebagai wakil al-Haqq. Uraian tersebut sesuati konsep Lyotard tentang fragmentasi, yaitu sebuah perlawanan untuk mencapai masyarakat yang baru di tanah Caruban.

Abdul Jalil juga menyatakan bahwa keindahan hidup manusia bukan saat berada di puncak kesuksesan, namun pada saat proses menjalankan hidupnya. Hal tersebut tampak pada data sebagai berikut.

Ibunda, sesungguhnya keindahan perjalanan hidup manusia bukanlah saat ia berada di puncak kehidupan yang sejati. Ibarat seseorang mendaki gunung, keindahan perjalanan hidup bukanlah kebanggaan dan bukan pula kegembiraan saat ia meninggalkan rumah, keluarga, kampung halaman, dan merangkak di antara tebing- tebing yang curam itulah keindahan dari sebuah perjalanan hidup."(D16/AS-SPPASSJ/3-47)

Data tersebut menjelaskan ketidaksetujuan Abdul jalil bahwa keindahan perjalanan hidup manusia terletak pada puncak kehidupan. Abdul Jalil mengungkapkan bahwa keindahan hidup seseorang terletak pada saat berani meninggalkan kenikmatan dan berani melewati cobaan dan ujiaan. Uraian tersbeut sesuai dengan konsep Lyotard tentang fragmentasi, yaitu Abdul Jalil tidak sependapat bahwa keindahan hidup berada pada puncak kehidupan, melainkan terdapat saat manusia menjali prosesnya dan keluar dari kenyamanan.

4. Paralogi dalam Novel Sang Pembaharu Perjuangan dan Ajaran Syaikh Siti Jenar Karya Agus Sunyoto

Paralogi merupakan keputusan yang diambil dari sebuah kesepakaan guna memperbaiki sebuah tatanan aturan yang berlaku. Dahulu Pakuwon Caruban tidak lagi berada di bawah kekuasaan maharaja Sunda, melainkan di bawah Demak. Keputusan yang diambil Raden Kusen adalah keputusan sepihak. Hal tersebutmenimbulkan kemarahan orang Sunda. Akhirnya Sri Mangana menyamar sebagai Ki Samadullah untuk menggantikan Ki Danusella telah terbongkar, pihak kerajaan sunda tidak mengira bahwa Sri Mangana bukanlah orang lain melainkan pangrean walangsungsang, putera Raden Pamanah Rasa, cucu Prabu Dewa Niskala. Itu berarti Caruban yang baru adalah putera Maharaja Sunda karena Raden Pamanah Rasa setelah dilantik menajdi maharaja Sunda berganti nama menjadi Abhiseka Prabu Guru Dewata Prana Sri Baduga Maharaja Ratu Aji di Pakuan Pajajaran Sri Sang Ratu Dewata. Setelah utusan dari Pakuan Pajajaran yakin, kalau Sri Mangana adalah cucu Prabu Dewata Niskala, maka sangat gembira Raden Pamanah Rasa, kemudian beliau memutuskan untuk memilih seseorang untuk menyelesaikan samiddha. Pada novel SPPASSJ kesepakatan terjadi sewaktu menunjuk seseorang untuk menengahi masalah samiddha Caruban Larang, akhirnya Yang Mulia Ario Abdillah yang terpilih sebagi penengah. Hal tersebut tampak dalam data berikut.

Lalu, diputuskanlah oleh ayahandaku untuk menyelesaikan perkara samiddha melalui jalan damai perundingan. Demikianlah setelah melalui beberapa kali pertemuan akhirnya kedua belah pihak yang berselisih mencapai kesepakatan, yaitu Ario Abdillah Yang Dipertuan Palembang sebagai penengah. (D37/AS-SPPASSJ/3-83)

Data di atas menjelaskan bahwa telah terjadi kesepakatan antara Raden Pamanah Rasa dengan kedua belah pihak yang berselisih. Sebelumnya Raden Pamanah Rasa yang mengambil keputusan, karena dia yang yang berkuasa di daerah tersebut, tetapi dia juga mengajak rudingan pihak yang berselisih agar menemukan kesepakatan dan tidak menimbulkan perselisihan. Kesepakatan telah terjadi untuk menunjuk Yang Mulia Ario Abdillah sebagai penengah untuk masalah samiddha Caruban Larang. Raden Pamanah Rasa adalah putera maharaja Sunda yang saat itu berkuasa di daerah tersebut. Dia juga yang memiliki kewenangan dan 
kekuasaan untuk memutuskan sesuatu, atas usulannnya untuk memutuskan menyelesaikan perkara dengan kesepakatan. Uraian tersebut sesuai dengan konsep Lyotard tentang paralogi mengenai bahwa sebuah keputusan yang daimbil melalui kesepakatan bersama guna memperbaiki sebuah tatanan yaitu tentang tanah Samiddha.

Aku dan ayahanda asuhmu, Ki Samadullah telah terikat janji untuk tidak menceritakan kepada siapa pun tentang jati dirimu. Karena beliau akan mengangkat dirimu." Karena, beliau akan mengangkatmu sebagai Kuwu Caruban, pengantinya kelak. Jika orang-orang tahu bahwa engkau bukan putra kandung Ki Danusela, pastilah kelak mereka akan menolakmu untuk menggantikan kedudukanna sebagai Ketua Caruban. (38/AS-SPPASSJ/3-28)

Data tersebut menjelaskan bahwa Muthmainah dan Ki samudullah telah sepakat berjanji tidak menceritakan tentang Abdul Jalil kepada siapa saja, karena menurut nya kalau menceritakan tentang jati diri Abdul Jalil kepada semua oran, Abdul Jalil tidak jadi diangkat sebagai Ketua Caruban karena dia bukan kandung Ki Danusela. Uraian tersebut sesuai konsep Lyotard tentang paralogi oleh Muthmainah agar tidak menimbulkan penolakanterhadap kedudukannya sebgai kuwu Caruban. Parologi dalam novel SPPASSJ juga tampak ketika Sri Mangana mendukung Abdul Jalil untuk menggantikan Dang Hyang Semar. Hal tersebut nampak pada data berikut.

"Diam-diam ia bertekad mendukung Abdul Jalil untuk menggantikan kedudukan Dang Hyang Semar sebagaimana perjanjian yang telah dibuat kakeknya. Ia yakin Abdul Jalil tentu akan menjadi manusia bijak sebagaimana Dang Hyang Semar". (D39/AS-SPPASSJ/3-21)

Data di atas menjelaskan bahwa dukungan yang dilakukan Sri Mangana untuk mendukung Abdul Jalil merupakan suatu keputuisan yang telah dibuatnya dengan kakek Abdul Jalil. Uraian tersebut sesuai konsep Lyotard mengenai paralogi tentang sebua keputusan yang diambil Sri Mangana untuk mendukung Abdul Jalil.

\section{Instabilitas dalam Novel Sang Pembaharu Perjuangan dan Ajaran Syaikh Siti Jenar Karya Agus Sunyoto}

Instabilitas merupakan ketidakmapanan akan sesuatu kondisi tertentu. Pada novel SPPASSJ terdapat instabilitas yang dialami oleh Nyi Mas Gandasari, meskipun dia terkenal perempuan yang kuta, kekuatannya pun melebihi laki-laki, namun Nyi Mas Gandasari bisa emosi yang mendalam, seperti saat dia bertemu adiknya yaitu Abdul Jalil, dia lamgsung meluapkan emosinya dengan berlutut dan merangkaul Abdul Jalil. Hal tersebut nampak pada data berikut.

" Bagaikan selembar kain jatuh, dia duduk berlutut dan merangkul adik yang dirindukannya sambil menangis tersedu-sedu. Dia menjadi perempuan biasa yang berhati sangat lembut.” (D43/ASSPPASSJ/3-63)

Data tersebut menjelaskan bahwa Nyi Mas Gandasari mengalami perasaan yang tidak seperti biasa, karena dia adalah sosok wanita yang tangguh dan kuat menghadapi segala ujian. Namun, saat dia bertemu adiknya dia berubah menjadi wanita yang lemah lembut. Uraian tersebut sesuai dengan konsep Lyotard tentang instabilitas, yang merupakan ketidakstabilan yang dialami Nyi Mas Gandasari saat bertemu Abdul Jalil dia berubah menjadi wanita yang emosi dan lembut.

Dalam novel juga ditemukan instabilits yang terjadi kepada kalangan masyarakatyang menerima ajaran islam. Bagi kalangan tua menerima ajaran islam masih sulit, namun bagi kalangan muda mudah untuk menerima ajaranislam. Karena kalangan muda masyarakat Caruban masih sedikit mengalami kenangan tentang ajaran lama mereka, lain halnya dengan kalangan tua yang ajaran lama sudah menjadi kenangan, sehingga untuk menerima ajaran Islam lebih sulit. Uraian tersebut nampak pada berikut.

Kalangan muda yang menerima ajaran Islam sesungguhnya bukan saja disebabkan oleh hidayah yang mereka terima dari Allah SWT, melainkan rekaman kenangan mereka terhadap ajaran yang menganggap Tuhan berbentuk batu dan kayu yang dipahat itu belum terlalu kuat berurat dan berakar. Sementara kalangan tua yang memusuhi Nabi Muhammad Saw. selain tidak beroleh hidayah dari Allah SWT, juga rekaman kenangan terhadap ajaran lama mereka sudah berurat akar selama puluhan tahun. Bahkan pamanda Nabi Muhammad Saw., Abu Thalib, yang berjiwa mulia dan selalu membela dan melindunginya, tergolong kalangan tua yang sudah tercekam oleh ajaran lama tersebut sehingga dia sulit melepaskannya. (D44/AS-SPPASSJ/3-68)

Data tersebut menjelaskan bahwa penerimaaan ajaran Islam pada masyarakat Caruban dalam belum stabil. Bagi kalangan muda lebih muda menerima ajaran islam karena kenangan tentang ajaran lama masih sedikit, sedangkan kalangan tua lebih sulit untuk menerima ajaran Islam karena kenangan ajaran lamanya 
masih terkenang sampai memori otaknya. Uraian tersebut sesuai dengan konsep Lyotard tentang instabilitas. Hal itu disebebkan adaknya kenangan ajaran lamaa babi mereka, sehingga untuk ajaran baru, yaitu Islam belum merata dikalangan orang tua. Pada masyarakat Lemah Abang yang masih serakah dan rakus. Mereka tidak menyetujui ajaran Abdul Jalil. Mereka menganggap ajaran yang dibawa Abduil Jalil adalah sebuah ancaman. Hal tersebut tampak pada data berikut.

Sesungguhnya, sangat banyak manusia rakus dan serakah yan akan tidak suka dan membenci ajaranku di Lemah abang ini. Mereka tidak akan segan-segan menumpas ajaranku dan tatanan baru di Lemah Abang yang mereka anggap mengancam kepentingan pribadi mereka.(D45/AS-SPPASSJ/4114)

Data tersebut menjelaskan bahwa masyarakat Leamh Abang dalam keadaan tidak stabil, mereka mengalami kecemasan tentang ajaran yang dibawa oleh Abdul Jalil, bagi mereka ajaran Abdul Jalil merupakan sebuah ancaman. Uraian tersebut sesuai dengan konsep Lyotard tentang Instabilitas yang merupakan sebuah kerasahan yang dialami oleh masyarakat Lemah Abang atas ajaran yang dilakukan Abdul Jenar.

\section{Simpulan}

Kesimpulan penelitian ini terangkum dalam lima hal. Pertama, delegitimasi merupakan kondisi yang menunjukkan bahwa penolakan keputusan pemimpin atau penguasa pelaksana kekuasaan yang terdapat dalam data tersebut. Kedua, Permaianan bahasa merupakan sebuah ikatan sosial yang mempersatukan masyarakat dalam berkomunikasi. Permainan bahasa mampu menunjukkan kewenangan seseorang yang telah diberi mandat kewenangan. Dalam konteks permainan bahasa sebagai alat komunikasi, bahwa setiap klausa atau kalimat yang diucapkan atau disampaikan kepada orang lain, mengandung tiga aspek, yaitu pengirim, penerima, dan refrennya. Pihak pengirim pesan jelas memunyai posisi yang berwenang, yang menginginkan agar penerima pesan untuk melakukan tindakan yang diinginkannya. Menurut Lyotarad, kekuasaan seseorang bisa dilihat dari penggunaan bahasa atau permainan bahasa. Pendapat penguasa dapat dieprcaya kepada pendengarnya, hal tersebut bentuk kekuasaan dan legitimasi terhadap pendapat atau perintah penutur. Ketiga. Fragmentasi merujuk pada ketiadaan atau tidak berkembangnya koneksi di antara masyarakat dan pengelompokan masyarakat berdasarkan semua aspek. Fragmentasi berisi interupsi dan penjajaran yang mengacaukan kaidah-kaidah konvensionl. Keempat, Paralogi dalam novel. Paralogi merupakan keputusan yang diambil dari sebuah kesepakaan guna memperbaiki sebuah tatanan aturan yang berlaku. Kelima, Instabilitas dalam novel Instabilitas merupakan ketidakmapanan akan sesuatu kondisi tertentu.

\section{DAFTAR RUJUKAN}

Emzir. (2014). Metode Penelitian Kualitatif, Analisi Data. Jakarta: Raja Grafindo Persada.

Lyotard, J. F. (1984).The Postmodern Condition: A Report on Knowledge. Minnesota, USA: University of Minnesota Press.

Marshall, C \& Gretchen B. R. (2006). Designing Qualitative Research. London: Sage Publications.

Ramadhanti, D. (2018). Pembentukan Karakter Melalui Ungkapan Kepercayaan Rakyat Dalam Masyarakat Minangkabau. BASINDO : jurnal kajian bahasa, sastra Indonesia, dan pembelajarannya, 1(2), 72-78.

Sunyoto, A. (2004). Suluk Abdul Jalil Perjalanan Rohani Syaikh Siti Jenar (Buku Satu). Yogyakarta: PustakaSastra LKiS.

Sunyoto, A. (2004). Suluk Abdul Jalil Perjalanan Rohani Syaikh Siti Jenar Suluk Malang Sungsang (Buku Dua). Yogyakarta: PustakaSastra LKiS.

Sunyoto, A. (2004). Sang Pembaharu: Perjuangan dan Ajaran Syaikh Siti Jenar (Buku Tiga). Yogyakarta: Pustaka Sastra LKiS.

Sunyoto, A. (2004). Sang Pembaharu: Perjuangan dan Ajaran Syaikh Siti Jenar (Buku Empat). Yogyakarta: Pustaka Sastra LKiS.

Sunyoto, A. (2004). Sang Pembaharu: Perjuangan dan Ajaran Syaikh Siti Jenar ( Buku Lima). Yogyakarta: Pustaka Sastra LKiS.

Thomas, R.M. (2003). Blending Qualitative \& Quantitative. California: Corwin Press INC. 